First draft: September 21st 2006

This version: June $12^{\text {th }} 2007$

Preliminary draft, comments welcome

\title{
Institutional Determinants of Vertical Integration: Evidence from China
}

\author{
Joseph P.H. Fan ${ }^{\mathrm{a}}$, Jun Huang ${ }^{\mathrm{b}}$, Randall Morck ${ }^{\mathrm{c}}$, and Bernard Yeung ${ }^{\mathrm{d}}$
}

a. The Chinese University of Hong Kong; pjfan@cuhk.edu.hk, 852-2609-7839.

b. The Shanghai University of Finance \& Economics; sufehuang@gmail.com; 852-2696-1819.

c. University of Alberta and National Bureau of Economic Research; randall.morck@ualberta.ca; 1-780492-5683.

d. New York University; byeung@stern.nyu.edu; 1-212-998 0425.

We are most grateful for very helpful comments from Pedro Dal Bó and Larry White and other participants in seminars and conferences at the China International Conference in Finance (2007), the Harvard Business School, NYU, and the U of Copenhagen (2006). 


\title{
Institutional Determinants of Vertical Integration: Evidence from China
}

\author{
Joseph P.H. Fan, Jun Huang, Randall Morck, and Bernard Yeung
}

\begin{abstract}
In a world with no transaction costs, vertical integration is intrinsically inefficient because it reduces specialization and thus the exercise of comparative advantage among firm units. However, in reality transactions between separate firms carrying out vertically related activities have costs stemming from weak property rights protection, information asymmetry, or agency behavior, all of which lead to anticipated opportunistic behavior and ex ante distortions in investment. If these transaction difficulties cannot be overcome by contracting, because of weak institutions or insufficient market disciplinary forces, vertical integration can be a solution. Politically connected corporate insiders can use vertical integration to enhance their rent-seeking returns, though these are likely not shared with outside shareholders if this can be avoided.

Empirical validation of these hypotheses is most likely in emerging economies, where legal and market institutions are often weak despite substantial variation across sub-regions. Using Chinese data, we find that vertical integration is indeed importantly affected by institutional factors - it is more common in Chinese regions with weaker property rights protection, poorer local government quality, and stricter local regulation of market trades (which hampers market forces). Moreover, companies led by insiders with political connections are more likely to be vertically integrated.

Vertical integration is negatively associated with share value if the top corporate insider is politically connected, but positive associated with share value if the firm is independently audited.
\end{abstract}

JEL Classification: L22; P14; G38; P16

Key Words: Vertical Integration; Rent seeking; Property rights; Government quality 


\section{Institutional Determinants of Vertical Integration: Evidence from China}

\section{Introduction}

This paper examines institutional determinants and effects of vertical integration, which we define as the extent to which adjacent production stages are controlled by a common insider. In a perfect market, with no transaction costs, vertical integration is intrinsically inefficient because it prevents specialization and thus the exercise of comparative advantage across firm units. However, transactions between separate units carrying out vertically related activities can be difficult under some circumstances. These difficulties arise from weak property rights, information asymmetries, and agency problems, any or all of which lead to anticipatable opportunistic behavior and its consequent investment distortions. If weak legal institutions and weak market disciplinary forces prevent parties from contracting around such transaction difficulties, vertical integration is a possible solution (Williamson, 1975; Klein, Crawford and Alchian, 1978). However, corporate insiders with political connections, under these conditions, could also use vertical integration to magnify returns to political rent-seeking, including enhancing their monopoly power. Also, rent seeking insiders might use vertical integration to facilitate tunneling to benefit them and enrich their connections.

A voluminous empirical literature, mostly using data from a single advanced country (e.g., the U.S.) and often focusing on a single industry or company, finds support for the idea that integration is a response to concerns about opportunistic behavior (e.g., Teece,1976), Monteverde and Teece, 1982; Masten, 1984; Mulherin, 1986; Joskow, 1985; Ohanian,1994), Chipty, 2001, etc). The premise that transactions costs predict firm vertical integration, however, intrinsically relies on a country's institutions and legal property right systems affecting the relative costs of market versus in-house transactions, and hence influencing firm vertical integration decisions. To 
test the idea, cross-country data that reflect such institutional variation is helpful. The foreign direct investment literature argues, and empirically shows, that firms investing across borders resort to full ownership control (i.e., integration) when transaction difficulties intrinsic to the nature of the business are high (e.g., Henisz, 2000). Unfortunately, such studies do not shed clear light on the relationship between integration and legal or market institutions. The reason is that there are confounding considerations. For example, foreign and domestic firms have different capabilities in dealing with weak legal and market institutions as well as other non-contractible capabilities. These differences affect their roles as acquirers and acquired. The consequence is that the obtained results do not directly and cleanly speak to the relationship between legal and market institutions and integration.

Acemoglu, Johnson, and Mitton (2005) conduct a direct test: they find that vertical integration is more prevalent in countries with greater contracting costs and less developed credit markets. But these correlations almost disappear after controlling for industrial composition. They show, however, that vertical integration is significantly greater in countries with higher contracting costs and yet greater financial market development. Cross-country studies, however, often confront omitted variable problems, making observed relations hard to interpret. Data inconsistency and measurement bias could be issues as well. For example, Acemoglu et al. (2005) proxy for a firm's potential vertical integration intensity using data from the US input/output table, which may not be applicable to other countries. Also, their contracting cost is based on the number of steps required to collect a debt. But actual contracting costs might not be correlated with steps required if, for example, a highly efficient judicial system lets creditors execute a succession of steps quickly and cost-effectively.

To mitigate such problems, we examine the effects of different institutional factors on firm vertical integration in different parts of one country - China - whose transition economy provides a natural setting. Ample evidence indicates that respect to property rights is rare, 
bureaucratic rent-seeking is prevalent, and substantial resources remain under State control (Montinola, Qian and Weingast, 1995; Che and Qian, 1998; Allen, Qian and Qian, 2005; Cull and Xu, 2005; Fan, Wong and Zhang, 2007). Yet, because of China's size and decentralized economic and political systems (Qian and Weingast, 1996, 1997), there is wide variation in institutional quality across its various regions. This variation lets us empirically investigate the link between institutional quality and firm vertical integration within one country, thus mitigating the above mentioned econometric problems induced by unobserved country factors, such as language, culture and custom in cross-country studies.

Measuring the prevalence of vertical integration is difficult because complete firm level data are unavailable. We use all publicly listed firms (almost 1,000) from China's various regions and industry sectors, but miss unlisted enterprises. We utilize commodity flow information from China's input-output (IO) table to designate vertically related industries, a methodology developed by Fan and Lang (2000) and subsequently adopted in several other empirical studies (e.g., Acemoglu et al., 2004; Acemoglu, Johnson and Mitton, 2005; Fan and Goyal, 2006).

Controlling for other potentially influential factors, we find that vertical integration is more common in regions with weaker property rights protection, worse local government quality, and stricter local regulation of market trades (which restricts the market forces). Also, companies run by insiders with political connections are more likely to be vertically integrated.

The link observed between a firm's vertical integration and its market valuation, as reflected by its market to book ratio, depends on the setting. Vertical integration is negatively associated with firm value if its insiders are politically connected. But, the association turns positive if the firm's insiders are subject to monitoring by independent and credible outside auditors. Finally, vertical integration is most strongly positively linked to elevated firm market value if the firm has a politically connected insider whose incentives are aligned with public shareholders. These results are consistent with vertical integration being a response to weak 
institutions, but raising or lowering public shareholder wealth depending on whether or not insiders' incentives are aligned with public shareholders returns.

The paper proceeds as follows. Section 2 develops our hypotheses. Section 3 describes the sample, discusses empirical measures, and provides descriptive statistics. Our main results are reported in section 4. Section 5 investigates how firm performance correlates with vertical integration. Section 6 concludes.

\section{Hypotheses development}

This section discusses likely determinants of vertical integration and its impact on firm value.

\subsection{Transaction costs and vertical integration}

By vertical integration, we do not mean the simple integration of closely related production activities, like the washing and then the pressing of clothes. Rather, we mean the integration of activities that belong to distinctly identifiable separate industries. To illustrate, consider Weiqiao Group, the largest textile company in China. The group's primary business is producing textiles. But it also grows its own cotton, makes the cotton into yarn, weaves and fabricates the yarn into textiles, imprints the textiles with colors before selling them to customers, and operates its own electricity plant to power its other operations. Weiqiao exemplifies a degree of vertical integration that is commonplace Chinese phenomenon, but rare in developed market economies. Moreover, past decade witnessed numerous State owned and entrepreneur owned firms in China reshaping themselves into such vertically integrated structures.

Such extensive vertical integration might at first seem highly inefficient. Widespread vertical integration dilutes management's focus and creates "territorial" political conflicts inside the company (Milgrom and Roberts, 1988). More fundamentally, it undermines a basic advantage of free market economics - specialization. Intuitively, exercising comparative 
advantage lets an industrially specialized firm be more efficient in its operations and its investment in technology and future capability.

This argument must be reconsidered in the presence of high transaction costs. A vast literature suggests that substantial transaction difficulties induce vertical integration. Coase (1937) posits that transactions occur inside a firm (vertical integration) if the cost of arm's-length market transactions exceeds that of coordinating the transactions within the firm. Coase's insight triggered a series of writings (Williamson, 1973, 1975; Klein, Crawford and Alchian, 1978; Lucas, 1978; and many others), showing that transaction costs between units can make their integration optimal.

As Klein, Crawford, and Alchian (1978) and Williamson (1979) point out, transaction costs can be due to anticipated opportunistic behavior stemming from asset specificity, low transactions frequency, and uncertainty associated with the transactions in question. The cases they consider typically involve units engaging in upstream and downstream production. Each unit has to make a specialized investment in period one to prepare for production in period two. Once the investment is made, however, the resulting asset cannot easily be used for another purpose without a substantial loss in its value. Under these circumstances, a transacting party has an incentive to extract rents ex post - to demand a change in the transaction terms to its favor. Such opportunistic behavior is facilitated by information asymmetry around the transaction, whether due to genuinely exogenous unanticipated changes or to calculated rent-extraction. This foreseeable time-inconsistent behavior reduces the expected return to specialized investment, and therefore curtails it, resulting in a deadweight loss to society.

Asset specificity precipitates other problems. Two vertically related units could find that the values of their respective activities negatively affected by the effort put forth by the other unit. For example, incompetence by a production unit reduces the value of a design unit's proposal. Likewise, inconsistent design can reduce the learning intrinsic to production runs. In a similar vein, inadequate information sharing between vertically related units can reduce their ability to 
contain current costs, or to erroneous expectations about future market changes and thus suboptimal investment decisions. These examples show how agency problems and limited cooperation become more likely if units are separately owned, a situation under which the gains from effort are not fully appropriable while its cost is solely borne.

Another source of inefficiency is poor property rights enforcement. Consider again a designer working with an independent producer. After mastering the production processes required by the designer, the production unit can make extra runs and sell cheap knock offs. Equipped with knowledge acquired through working with the original designer, it could also build its own design unit, or share its knowledge with other designers, to gain more business. All these could harm the original designer's business. Likewise, the designer, after working with the producer, might learn much about production and the producer's trade secrets, and might sell this information to rival producers. Any buyer would capture the full benefit of this information, and so reduce its production cost. The price divides the gains between the designer and the second producer. The original producer faces tougher competition, and is less able to recover its initial investment in enhanced production capabilities. Given all these potential transactions costs, both the designer and producer, intent on protecting their property rights, might opt to pass on potentially profitable opportunities that would have required trusting the other unit.

Many such transaction difficulties can be avoided with legal contracts between the units, and by market forces that discipline the two units. A well functioning system of contract law and efficient markets can thus render vertical integration unnecessary.

First, well-specified and well-enforced legal contracts can mitigate opportunistic behavior and protect property rights. Reliably enforceable clauses in business contracts can substantially reduce the feasibility and gains from ex post bargaining to extract rents. Such contractual clauses can also reduce shirking, stipulate effort, govern information sharing, and predetermine degrees of cooperation. Carefully drafted legal contracts can precisely stipulate property rights and prohibit their infringement. 
Second, a free market serves as a disciplinary force. Visible transactions, carried out in the open, provide information about the behavior of firms and their insiders. Importunate shirking, inadequate performance, and disdain for property rights all inform subsequent potential business partners about the firm's likely behavior. While some transactions may be idiosyncratic or subject to asset-specific issues, a free market makes firms "on-going concerns" - their reputations as non-opportunistic players (Klein and Leffler, 1981) determine their future business opportunities.

Legal and market remedies are mutually reinforcing. If laws are costly to enforce and contracts are uncertain devices for committing to promises, a mixed solution partially enforced by laws and partially by market mechanisms might be more effective than reliance on one or the other alone. The presence of a "thick" market facilitates the detection of violations of contractual terms. At the same time, sound legal enforcement of contractual rights makes future opportunistic behavior easier to preclude, and thus expands investment opportunities and increases market "thickness".

\subsection{Determinants of Vertical Integration}

The above suggests that vertical integration is more likely where hold-up and property rights concerns are more serious; that is where the legal systems and market forces are too weak to enforce implicit, or even explicit, contracts. ${ }^{1}$ Our argument aligns with other work describing firms forming internal markets to overcome poor institutions (Khanna and Palepu, 1999).

Below, we develop several hypotheses by applying this logic to China. China provides a natural testing ground because of the substantial variation in both the strength of market forces and the quality of institutions across its regions. This variation, against a similar cultural background, provides a unique opportunity to examine the roles of market and legal institutions

\footnotetext{
${ }^{1}$ Another concern is the intrinsic importance of information sharing and general cooperation among vertically related units, like steel melting, molding, and casting. This intrinsic "relatedness" is basically an industry effect. Because it is not a central focus of the paper, we control for it using industry dummies.
} 
in firm vertical integration decisions. We can thus supplement prior studies of firm vertical integration within a single country, which focus on firm-level or industry-level determinants, without attracting the caveats about latent cultural differences that weaken cross-country studies.

\subsubsection{Asset specificity and uncertainty}

A basic premise of the transaction cost theory is that high potential hold-up costs induce vertical integration. To capture potential hold-up costs, we use the transportation infrastructure available to a firm in a region (province). Poor transportation infrastructure limits the firm's alternative business partners, and so aggravates post-contract bilateral bargaining problems. Hold-up problems intrinsic to this situation should induce vertical integration. However, poor infrastructure alone is not a sufficient condition for vertical integration, for the associated hold-up problem could be mitigated easily via an enforceable legal contract. Contractual difficulties arise if the firms also face nontrivial uncertainty as to the contract's enforcement (see, e.g., Carlton, 1979).

Hence, our starting point is that, ceteris paribus, a firm is likely to be more vertically integrated if its transactions are subject to high performance uncertainty and it is located in a region with poor transportation infrastructure.

\subsubsection{Institutional factors}

The general discussion in section 2.1 points to vertical integration being more prevalent where legal protection of property rights is weaker and markets are less developed and so exert feebler disciplinary forces. Using this logic, we identify determinants that should raise Chinese firms' tendency to integrate vertically.

Our first, simplest, and most obvious hypothesis is: 
Vertical integration should be more extensive in firms located in regions with weak legal protection of private property rights.

China's ubiquitous government intervention weakens private property rights and thus likely induces vertical integration. An illustration clarifies. In the earlier example, Weiqiao Group generates its own power to ensure the smooth operation of its textile plants. The reason is that heavy-handed regulation discourages entry to protect inefficient and unreliable State-owned electricity enterprises. These enterprises might renege on any commitments to supply electricity, so Weiqiao found vertical integration with an in-house electricity plant necessary. Interestingly, Weiqiao found it generated more electricity than it needed. Forbidden from selling power, Weiqiao began refining aluminium to make profitable use of its excess electricity - an activity not obviously related to its core textiles operations, but one clearly vertically related to aluminium production, which requires vast amounts of electricity.

Heavy regulation raises transactions costs, even for very standard transactions (Stigler, 1951) and stunts the development of market disciplinary forces. As explained in the previous section, the market's disciplinary forces also mitigate opportunistic behavior. Hence, our second hypothesis is:

A firm is more likely to adopt vertical integration strategy where its associated input and/or product markets are heavily regulated and/or underdeveloped.

Onerous regulations limiting the right to operate a business in China lead to several important considerations. Bureaucrats' powers to allocate these rights, and to interfere in businesses' operations, foster a specialized class of rent-seeking firms, which gain business opportunities by lobbying bureaucrats, having corporate insiders serve as bureaucrats, or advancing insiders' relatives within State and Party bureaucracies. These rent-seeking firms 
often become localized monopolies. Such local monopolists would opt for vertical integration to avoid "double marginalization"- especially where contracting options are limited (see, e.g., Cabral, 2000). ${ }^{2}$ They might also extend the scope of monopoly power by expanding upstream and downstream, using political clout to foreclose competition in those industries as well. State and Party officials might welcome such monopolies - corrupt officials because they capture part of the monopoly rents created, but also honest officials who find dealing with a single firm simplifies social engineering negotiations with business. Therefore, our third hypothesis is:

The more deeply a firm is connected with official bureaucrats, the more vertically integrated is the firm's business structure.

At a more general level, what matters is not regulation per se, but the quality of government. A poor quality government is rife with bureaucrats intent on extracting rents, collecting bribes, or even explicitly expropriating private property. In such an environment, for the reasons detailed above, firms connected with government bureaucrats would vertically integrate to enhance their rent-extraction, while unconnected firms would do the same to shield themselves from rent extraction.

Hence, another hypothesis is:

Firms are more likely to integrate vertically in regions with low quality government.

\footnotetext{
2 "Double marginalization" occurs when vertically related monopolists, each maximizing monopoly profits separately, fail to internalize the implication of one's high price on the other's profits. Coordinating vertically integrated monopoly pricing, by avoiding such "double marginalization", increases the monopolists' joint profits.
} 
In summary, we expect a firm to be more vertically integrated if its managers are politically connected and if it lies in a Chinese province or special district characterized by poor quality government, weak property rights protection, and/or ill-developed markets. ${ }^{3}$

\subsection{Vertical integration and firm value}

Our discussion points to institutional weaknesses of the sorts described above inducing vertical integration; but vertical integration could reflect either efficiency enhancement or rent-seeking, or both. While vertically integrated firms might generate higher cash flows, their insiders and their political connected parties might also appropriate most of these gains. As a consequence, the public shareholders of listed firms undertaking this strategy might see few benefits. Indeed, vertically related transactions might actually facilitate insiders' aggressive tunneling of cash flows out of the firm, perhaps even rendering public shareholder wealth negatively related to vertical integration. Only if the insiders could precommit to effective incentive alignment and monitoring would outside shareholders capture some of these vertical integration benefits.

We therefore expect that

1. Firm value is non-positively, and likely negatively, related to vertical integration if the firm is controlled by a rent extracting insider,

and

2. Firm value is positively related to vertical integration if incentive and monitoring devices prevent wealth extraction by insiders and bureaucrats.

\footnotetext{
${ }^{3}$ Khanna and Oberholzer-Gee (2006) show evidence that government interference within each province is correlated with the existence of large firms. They argue that either interference can protect incumbents or that incumbent must attain a certain size to combat interference.
} 
At this point, we need to clarify a concern. Our hypotheses point to politically connected and privileged insiders vertically expanding their firms for their own benefit in regions where government bureaucratic influence is pervasive, legal property rights protection is weak, and market disciplinary forces are feeble. The concern is whether these insiders would organize this vertical expansion as vertical integration within a single firm, or as a group of vertically related firms all controlled by them, perhaps via pyramiding control blocks. Possibly, both are happening. ${ }^{4}$ We currently have insufficient information to explore this issue. Note however, that the more widespread the use of distinct firms under common control, the less likely we are to find support for our empirical hypotheses.

\section{Data, measurement, and basic statistics}

This section describes the sample and our measure of vertical integration, and then explores patterns of firm vertical integration.

\subsection{The Sample}

Our sample includes most companies listed on the Shanghai and Shenzhen stock exchanges from 2001 to 2003. The China Securities Regulatory Commission requires that listed companies disclose segment information for all business segments comprising more than $10 \%$ of consolidated sales, assets or profits. Disclosed information about a given segment typically includes an industry name, a description of products or services, and segment sales, costs and profits. We manually collect these data from annual reports starting in 2001, since from that year on coverage and reporting quality are substantially improved.

\footnotetext{
${ }^{4}$ Further research to identify factors that influence an insider's choice: vertical integration in a single firm, or a group of vertically related firms under common control, or a mixture of these. We relegate these inquires for future research.
} 
Companies reporting non-positive sales or incomplete segment sales and industry sector information are dropped. Financial firms are excluded because their financial statements are not comparable to those of manufacturing firms. Firms primarily in public utility sectors are excluded because their business decisions are strictly regulated. Our final sample thus consists of 1,052 firms and 2,765 firm-year observations.

Table 1 describes the sample by year and industry. The sample firms account for almost 80 percent of listed companies. We define a firm's primary industry its largest segment's broad industry affiliation. Our firms' primary industries span the whole economy, with the most common being the machinery, equipment, and instrument sector, followed by the commerce (trade) sector, the petroleum and chemicals sector, and the glass, minerals and metals sector.

[Table 1 about here]

\subsection{Vertical Integration Measures}

We modify the methodology of Fan and Lang (2000) for measuring firm vertical integration. Given that direct firm-level data on vertical integration are unavailable, we utilize commodity flow information in the national economy's input-output matrix and a firm's industry-segment data to construct an index that proxies for the firm's potential vertical integration intensity. The construction of the vertical integration measure involves two steps.

In the first, we create two matrices of inter-industry vertical relatedness coefficients. This involves computing the coefficients between each pair of 124 industries defined in the 1997 Chinese input-output table. The table reports, for each pair of industries $i$ and $j$, the dollar value input from industry $i$ in producing industry $j$ 's total output. We denote this fraction $v_{i j}$. If $v_{i j}$ is large, this suggests an opportunity for a firm in $i$ to integrate into $j$. Conversely, a high $v_{j i}$ 
suggests an opportunity for $i$ to integrate into $j$. We define the vertical relatedness coefficient between industries $i$ and $j$ either as $V_{i j}=\frac{1}{2}\left(v_{i j}+v_{j i}\right)$ or, alternatively, as $V_{i j}=\max \left(v_{i j}, v_{j i}\right)$.

In the second step, a firm-level vertical integration measure is constructed by computing the weighted average vertical relatedness coefficients of each pair of its segments, excluding same-segment pairs. The firm vertical integration measure is defined as $V=\frac{1}{n-1} \sum_{i=1}^{n} w_{i} \sum_{j \neq i} V_{i j}$, where $w_{i}$ is the sales weight of segment $i$. The sum of the sales-weighted vertical relatedness coefficients is divided by $n-1$ to account for the weighted sum increasing with the number of segments. ${ }^{5}$ We then define $V_{\text {mean }}$ and $V_{\max }$ to signify whether the mean or maximum of $v_{i j}$ and $v_{j i}$ is used to calculate $V_{i j}$. For a one-industry firm $(n=1)$, we set both $V_{\text {mean }}$ and $V_{\max }$ to zero.

An example illustrates. Huangshan Tourism Development Co., Ltd has three segments: tour operation, hotels, and transportation, accounting for $51 \%, 24 \%$, and $25 \%$ of firm sales, respectively. Using the input-output table, we estimate that tour operation employs 0.0700 yuan of hotel services to produce one yuan of output, and conversely hotels consume 0.0020 yuan of tour operation products for every yuan of output generated. The mean inter-industry relatedness coefficient of tour operation with hotels, $V_{i j}$, is thus estimated as 0.0360 , the average of the two input requirement ratios. Similarly, the mean coefficient of hotels with transportation is 0.0023 , and that of tour operation with transportation is 0.0233 . The equation above then lets us estimate the overall extent of vertical integration of the firm, with $V_{\text {mean }}$, defined as $1 / 2 \times[51 \% \times(0.0360+$ $0.0233)+24 \% \times(0.0023+0.0360)+25 \% \times(0.0233+0.0023)]$, or 0.0229.

In other words, a firm's level of vertical integration is the weighted average of the vertical relatedness coefficients (based on economy averages) of all pairs of industries in which the firm operates.

\footnotetext{
${ }^{5}$ For example, consider a three-segment firm with one-third of its sales in each industry. If the vertical relatedness coefficients for pairs of the segments were each one, the weighted sum of each pair of vertical coefficients is two. Dividing this sum by two (three minus one) rescales the vertical measure back to one. Unadjusted, the sum would rise with the number of segments.
} 
We calculate $V_{\text {mean }}$ and $V_{\max }$ for each firm each year. Table 2 summarizes these vertical integration measures. Panels A and B report the mean, median, standard deviation, minimum and maximum of $V_{\text {mean }}$ and $V_{\max }$, respectively. The sample averages of $V_{\text {mean }}$ and $V_{\text {max }}$ are 0.014 and 0.025 , respectively. That is, the firms potentially could transact 1.4 or 2.5 fen (the Chinese unit for "cent"), depending on which measure is used, of its business dealings with in-house affiliates, for every yuan of output it produces. The average degree of vertical integration does not change significantly in terms of both $V_{\text {mean }}$ and $V_{\max }$ from 2001 to 2003. Across the 14 broad industries, vertical integration potential is most pronounced in mining; agriculture, forestry and fishing; textile, apparel and leather; and glass, minerals, and metals. Vertical integration potential is lowest in real estate; medicine and biological products; and publishing, motion pictures and arts.

[Table 2 about here]

\subsection{Focal Independent variables}

This section describes our focal independent variables, which capture determinants of vertical integration.

\section{Asset Specificity and Uncertainty}

Vertical integration is a response to asset specificity and uncertainty associated with transactions. Asset specificity can reflect industry characteristics or characteristics of the broader environment. We capture the former with industry fixed effects. We capture the latter with a key institutional feature - the quality of the regional transportation infrastructure, the total length of railways, waterways, and highways in the province divided by its total geographic area. Poor regional transportation infrastructure restricts parties' ability to find alternative business partners, and so heightens asset specificity problems, aggravating potential hold-up problems, and so elevating the costs of market transactions. 
We gauge performance uncertainty by input price uncertainty, as in Lieberman (1991) and Fan (2000). This is the standard error of the residual of an industry segment's annual inflation adjusted primary input price index regressed on a time trend from 1980 to 2001. Higher price uncertainty should make vertical integration more likely because this too raises arm's-length transactions costs. All else equal, this effect should be more pronounced where asset specificity hold-up problems are also more severe. That is, higher price uncertainty and worse transportation infrastructure together should induce even more vertical integration.

\section{Institutional factors}

Section 2 hypothesizes that vertical integration is affected by several institutional factors - the extent of legal property rights protection, government quality, and market development.

We measure local legal property rights protection using an index, developed by Fan and Wang $(2001,2002,2003)$, that reflects the frequency of lawsuits and the efficiency of courts in each province or special district. The frequency of lawsuits is defined as the number of business or economic lawsuits scaled by a location's GDP in constant yuan. Ordinarily, the frequency of lawsuits need not have a monotonic relationship with legal property rights protection. Lawsuits can be frivolous and excessive. Or, contracts can be so well honored that lawsuits are rare. In the Chinese context, both cases are unlikely. The use of the judicial system to enforce one's contractual and property rights is only beginning to seem practicable, and to a varying degree across provinces. Court efficiency is defined as the number of economic or business lawsuits concluded by the court in a year divided by number of cases filed that year. ${ }^{6}$ A principal component analysis is performed on the above two indices (lawsuit frequency and court efficiency) to derive the property rights index of Fan and Wang (2001).

\footnotetext{
${ }^{6}$ Specifically, the "frequency of lawsuits" index level is defined as $\left(S_{\max }-S_{i}\right) /\left(S_{\max }-S_{\min }\right) \times 10$, where $S_{i}$ is the number of lawsuits divided by provincial GDP and $S_{\min }$ and $S_{\max }$ are, respectively, the minimum and maximum $S_{i}$ among the 31 provinces and special districts in China. The "court efficiency" of region i is $\left(C_{i}\right.$ $\left.-C_{\min }\right) /\left(\mathrm{C}_{\max }-\mathrm{C}_{\min }\right) \times 10$, where $C_{i}$ is the number of economic or business lawsuits concluded by the court in a year divided by number of cases filed in the year; and with $C_{\min }$ and $C_{\max }$ the minimum and maximum, respectively, of $C_{i}$ across Chinese provinces and special districts.
} 
Our measure of local government quality is an index of government services quality, available in The Annual Report of Urban Competitiveness in China. ${ }^{7}$ The index grades local government service quality based on three criteria: the level of bureaucratization, the frequency of government expropriations, and the level of citizen satisfaction. This index is constructed at the city level, so we aggregate it to the province level index by taking an average across all cities in province. The government quality index is constructed by Chinese Academy of Social Science.

Finally, for market development we use the region's GDP divided by the regional government's budget. If this index is larger, the province's resources are more completely allocated by markets rather than the bureaucrats (Fan and Wang, 2001, 2002, 2003). Under China's communist regime, governments traditionally play an important role of allocating resources far beyond spending on education, infrastructure, social security, and the provision of standard public goods like policing and defence.

\section{Rent-seeking Potential}

Section 2 also points out that vertical integration might be motivated by rent-seeking. We construct a set of variables to capture firm rent-seeking potential.

Following Fan, Wong, and Zhang (2007), our first variable is CEO affiliation, an indicator variable set to one if the firm's CEO is (or has been) a bureaucrat with the central government, the regional government, or an industry bureau. Our second measure, business privilege is also an indicator variable, here set to one if one of the firm's line of business is a heavily regulated industry (electricity, communication, transportation, mining, metal, or petroleum industry) and to zero otherwise. In China, the right to operate in these industries is highly restricted, and must be granted by the State. Corporate insiders with government backgrounds, or who have obtained the right to operate in a heavily regulated industry, are likely to be politically connected; we therefore take these two variables as reflecting political rent-

\footnotetext{
${ }^{7}$ This report is published by Social Science Academic Press in 2004.
} 
seeking ability. We assume such ability opens further political rent-seeking opportunities, and hence creates superior access to business opportunities.

Our third measure of rent seeking is long-term financial leverage, measured by long-term debt over total assets. Politically favored firms typically have greater access to long-term bank loans (Sapienza, 2004; Khawaja and Mian, 2005). We therefore define financial leverage as one if a firm's long-term debt over total assets is above the median for all firms in that province, and to zero otherwise. Note that besides this variable has a potential alternative interpretation - better access to capital facilitates acquisitions, including acquisitions of vertically related firms.

\section{Firm level monitoring}

The relationship of vertical integration to firm value is affected by the extents to which insiders are monitored and their incentives are aligned with public shareholder value. To capture monitoring and incentive alignment, we use an indicator variable denoted auditor, set to one if the firm's external auditor is one of the international "big-four", and to zero otherwise. Evidence from the accounting literature suggests that emerging market firms with "big-four" auditors are more transparent to investors and have lower costs of capital than firms with other auditors (see e.g., Titman and Truman, 1986). In China, many auditors are small businesses, and may not even have professional accreditation. In contrast, the "big four" are large independent auditors with strong international reputations and experience with more demanding and rigorous auditing standards abroad. We expect that insiders scrutinized by "big four" auditors are less likely to appropriate wealth from their firms, including wealth accumulated via political rent seeking. Note that this variable could reflect self-selection, rather than auditing effectiveness.

\section{Other controls}


Several additional variables are considered as controls. New firms might be less vertically integrated than old firms simply because it takes time to build up vertical integration. We capture this by the number of years during which the firm was listed, denoted years listed. We include provincial per capita gross domestic product (GDP) to account for the effects of regional economic conditions on firm organizational structure. This control also mitigates the possibility that our transportation infrastructure and institutional variables might proxy for general development.

The Appendix summarizes the definitions and data sources of the variables employed. Table 3 reports basic statistics on pooled firm-year and province-year data. The number of observations differs across variables, mainly because some are region-level while others firmlevel. The government quality variable has fewer observations than other region-level variables because it is available only in 2003. Substantial variation in institutional quality across China's regions is confirmed by the substantial variation in region-level institutional variables. ${ }^{8}$

[Table 3 about here]

Table 4 provides Pearson correlation coefficients. The institutional and control variables are generally not highly correlated, so their inclusion as controls in the regressions below ought not to induce multicollinearity problems. However, multicollinearity may be present between the transportation infrastructure variable and the property rights index $(\rho=0.495)$, and also the provincial level GDP per capita $(\rho=0.907)$.

[Table 4 about here]

\footnotetext{
${ }^{8}$ The minimum of market allocation seems to be an outliner. We winsorize it later in the regressions, and the results remain qualitatively similar.
} 


\section{Vertical integration and its determinants}

This section empirically examines the roles of the institutional factors in explaining vertical integration. We begin by examining the Pearson correlation coefficients of the vertical integration indexes with the institutional and firm variables in Table 4. Vertical integration, whether measured by $V_{\text {mean }}$ or $V_{\max }$, is significantly negatively correlated with legal property rights, government quality, and market development. The rent seeking variables - the CEO's political affiliation, the right to operate in heavily regulated sectors, and access to long-term debt - all correlate significantly positively with $V_{\text {mean }}$ and $V_{\max }$. Vertical integration correlates significantly positively with price uncertainty, but insignificantly negatively with transportation infrastructure. These correlations are consistent with our hypotheses.

Table 5 reports differences in mean and median vertical integration levels between firms with high versus low rent-seeking potential. We alternately use CEO connections with bureaucrats, rights to operate in regulated industries, and access to long-term bank loans to identify high rent seeking potential firms. The table clearly confirms that firms led by politically connected CEOs, operating in heavily regulated sectors, and with superior access to long-term bank loans exhibit greater degrees of vertical integration than other firms. These bivariate comparison results are consistent with the correlations in Table 4, and with the hypothesis that vertical integration in China is associated with rent-seeking as well as transactions costs.

\section{[Table 5 about here]}

Confirming these hypotheses more reliably requires multiple regression analysis to control for other factors that might affect vertical integration. We run OLS regressions on pooled firm-year data. Our province level variables exhibit no variation across firms within each province, and several firm variables have only small variations over time. To avoid upward 
biased t-statistics, we calculate Huber-White clustered standard errors by year and by firm, as recommended by Petersen (2005). If a firm's gains from potential vertical integration are outweighed by the cost, it should not opt to integrate vertically. This means our $V_{\text {mean }}$ or $V_{\max }$ variables are truncated at zero. We therefore also include a standard Heckman correction in all our regressions. The Heckman procedure involves two stages. In the first, a probit regression is run to address whether a firm choose to integrate vertically or not. The dependent variable is a binary variable equal to one if a firm is in more than one industry, and to zero otherwise. The independent variables include firm size (the natural log of firm assets), market to book equity ratio, the percentage ownership stake of the state, years listed, plus industry and year dummy variables. The first-stage results are reported in Panel A of Table 6. In the second stage, the vertical integration model is estimated using OLS, controlling for truncation bias by including an inverse Mill's ratio, denoted as $\lambda$, predicted by the first stage.

Panel B of Table 6 reports regressions explaining $V_{\text {mean }}$. Regressions explaining $V_{\max }$ generate very similar results, and so are not shown to save space. Column (1) reports the coefficients of a basic model including price uncertainty, transportation infrastructure, the interaction between these two variables, $\lambda$, years listed, GDP per capita, and industry and year fixed effects. ${ }^{9}$

The results show vertical integration positively related to price uncertainty, unrelated to transportation infrastructure, and negatively related to the interaction between the two. These results are consistent with a transaction cost explanation; that is, with high price uncertainty raising transactions costs, and hence inducing firm to integrate vertically to bypass costly market transactions. The interaction term is consistent with weak transportation infrastructure, when coupled with uncertainty, inducing further vertical integration.

[Table 6 about here]

\footnotetext{
${ }^{9}$ We use heteroskedasticity-consistent $t$ ratios allowing for firm and year clustering.
} 
Column (2) of Table 6 shows vertical integration negatively associated with the quality of the region's legal property rights protection, government, and market development. These institutional effects are economically significant. For example, setting all the independent variables at their means, a ten percent improvement in the property rights reduces vertical integration $\left(V_{\text {mean }}\right)$ by 4.1 percent, almost 1.65 times larger than the standard deviation of the vertical integration measure. The remaining independent variables exhibit the same pattern as before.

Columns (3) through (5) further include the three firm-level variables proxying for rentseeking. Vertical integration is more evident in firms that have politically connected CEOs, rights to operate in highly regulated industries, and superior access to long-term debt. The coefficients of the other independent variables remain qualitatively unchanged.

The control variables behave as expected: vertical integration is unrelated to GDP per capita, but is negatively related to years listed.

As robustness checks, we rerun our regressions as tobits, and generate qualitatively similar results - by which we mean patterns of signs and significance similar to those in the tables. As a further robustness check, we apply an approximate inverse logistic function, transforming $V_{\text {mean }}$ into $V^{\prime}=\ln \left[1 /\left(1-V_{\text {mean }}\right)\right]$. . We then run tobit regressions, and alternatively OLS regressions with Heckman correction, and again generate similar results to those shown. Rerunning the regressions without clustering also generates qualitatively similar results, though with artificially enhanced t-statistics.

We also repeat our statistical work excluding the "wholesale' and "retail" industries (labelled "commerce" in Table 2) because integration data in these industries might, by nature, be very different from those in other industries. In doing this, we suppress about four hundred observations, but our results do not change qualitatively. 
Overall, Table 6 is consistent with vertical integration being an important organizational response to weak legal property rights protection, laggard market development, and generally low quality government. The results are also consistent with vertical integration being associated with political rent-seeking.

\section{Vertical integration, Transparency, and Firm Value}

This section examines the relationship between vertical integration and firm performance, and how improved firm transparency affects that relationship. We gauge firm performance as valuation by public shareholder. This is clearly not the firm's contribution to social welfare, and precludes us from linking microeconomic efficiency firmly to vertical integration. Nonetheless, shareholder valuation measures value creation shared with outside investors, and thus reflects, albeit imperfectly, the implications of transactions costs on vertical integration and corporate performance. In fact, we exploit this imperfection by contrasting our findings in firms with "big four" auditors, whose enhanced transparency likely permits public shareholder a greater share of any value created by vertical integration, with other listed firms, whose insiders are better able to appropriate any such value added.

We gauge firm performance by market-to-book ratios, which we take as proxies for Tobin's average $q$. Specifically, we define this as the sum of the market value of tradable equity, book value of untradable equity, and book value of debt, all divided by total assets. Because a substantial part of the equity of a typical Chinese listed state controlled company is untradable classes of shares held by various state organs, we take these at book value. ${ }^{10}$ The value of tradable shares is estimated as the fiscal year-end closing price per share times the number of tradable shares.

\footnotetext{
${ }^{10}$ As a robustness check, we redefine firm value excluding non-tradable government owned shares - i.e. setting their value to zero. Repeating our regressions with this re-defined q generates qualitatively identical results throughout.
} 
In our basic model, Tobin's average $q$ ratio is regressed on $V_{\text {mean }}$ and a set of control variables, including firm diversification, size, debt, growth, state ownership, and years listed, plus industry and year fixed effects. ${ }^{11}$

Diversification is defined as the number of industry segments a firm possesses. The finance literature links diversification to firm value. However, it is unclear whether or not we should explicitly include diversification as an explanatory variable. On the one hand, horizontal diversification is not the same as vertical integration, so we should differentiate the two. Moreover, vertically integrated firms operate in multiple segments. Without entering the number of segments, our vertical integration index may inadvertently capture horizontal diversification. On the other hand, by entering the number of segments on the right hand side, we may double count the impact of integration and induce a multicollinearity problem. We opt to include the variable, but also eliminate it as a robustness check. Our results are essentially not affected if we exclude the diversification variable.

Firm size and years listed are defined as above. We measure debt as total debt divided by total assets. Growth is the percentage annual growth in sales from the previous to the current year. State ownership is the percentage of tradable plus nontradable shares owned by governments directly or through State organs. We include the variable because state ownership can be intrinsically related to firm value. ${ }^{12}$ The regressions are OLS, with year and firm clustering, as recommended by Petersen (2005).

In conjunction with our basic regressions, we again run Heckman regressions, but now as treatment effect adjustments. We do this because a firm's choice to integrate vertically may depend on background factors that also affect valuation. We thus run a first stage regression wherein we explain firms' choices to integrate vertically or not, and then include an inverse

\footnotetext{
${ }^{11}$ Using $V_{\max }$ as the independent variable generates results qualitatively similar to those in the table.

12 This is because state ownership can imply pressure to optimize social objectives, rather than economic efficiency; and also because state ownership can be indicative of importance in the political arena, which can affect operating efficiency bargaining power, and other related matters, and thus firm performance.
} 
Mill's ratio, $\lambda$, in the second stage regressions as a treatment effect adjustment to provide us with a clearer measure of the effect of vertical integration on valuations. The result of the first stage regression for vertical integration has been reported previously in Panel A of Table 6.

Panel B of Table 7 then reports the second stage results. Column (1) reveals that vertical integration is unrelated to average $q$, though several control variables are significant. Specifically, diversification, state ownership and size are negative, but debt and years listed are positive.

[Table 7 about here]

We next see if vertical integration associated with rent-seeking has different valuation implications. To do this, we modify the basic regression by including each of the three rent seeking variables in columns (2) through (4).

Average $q$ remains unrelated to $V_{\text {mean }}$, except in the column using superior assess to capital to proxy for rent-seeking. In that case, vertical integration is positively and marginally significantly associated with $q$.

The coefficients of the rent-seeking variables indicate different relations with average $q$. Politically connected CEOs and rights to operate in restricted industries are both positively related to average $q$. In contrast, financial leverage is weakly negatively related to average $q$, consistent with most firms being overly leveraged - additional access to loans does not augment, but rather reduces shareholder value.

Column (2) through (4) reveal interactions of $V_{\text {mean }}$ and rent-seeking to be significantly negative regardless of the rent-seeking proxy employed. These results are consistent with vertical integration being linked to political rent seeking and adversely affecting firm valuations. At first glance, this seems inconsistent, for rent seeking ability should be a competitive advantage in China's weak institutional environments. However, the result is consistent with insiders, rather 
than public shareholders, reaping most of the benefits associated with rent seeking augmenting vertical integration and vertical integration facilitates rent-seeking.

Insiders subject to scrutiny by sophisticated auditors may be less apt to appropriate such benefits. They subject themselves to such scrutiny voluntarily - to send a positive signal to improve their firms' prospects for obtaining financing in the future. Or, they may do this involuntarily, perhaps because their predecessors did so. To deal with the issue, we incorporate as a regressor an indicator variable set to one for firms audited by a "Big Four" auditor, and to zero otherwise.

We thus run another first stage regression, wherein we explain firms' choices of auditors. Again, we use a probit to estimate an inverse Mill's ratio, this time denoted $\lambda_{2}$. The dependent variable is an indicator set to one if the external auditor is 'big four'. The independent variables are firm size, asset structure (current asset to current liabilities), accounts receivable over assets, and inventory over assets. These variables are commonly used in the accounting literature, e.g., as in Chaney, Jeter and Shivakumar (2004), but we do not include commonly used predictors that are known to be correlated with q, like ROA and long term debt over assets. The results of this regression are in Panel A of Table 7.

We then run a second stage regression considering a "big four" auditor as another "treatment" variable and including its inverse Mill's ratio, $\lambda_{2}$, estimated in the first stage, as a treatment effect adjustment. As in Table 6, we also include a treatment effect adjustment for vertical integration, again denoted $\lambda$ and estimated in Panel A of that table.

The second stage results show average $q$ significantly positively related to a "big four" auditor, but the interaction term between auditor and $V_{\text {mean }}$ is insignificant. Overall, these results associate brand-name auditors with higher firm valuations, consistent with credible firms self-selecting to be audited by reputable auditors and with auditors' 
reputation lending credibility to the firm. However, opting for brand-name auditor is not associated with different valuations in differently vertically integrated firms.

To see if credible external monitoring induces insiders to share with public shareholders any benefits of vertical integration associated with political rent seeking, we now include a three-way interaction term among $V_{\text {mean }}$, a dummy for the use of a brandname auditor, and each of the rent seeking variables in turn.

These interaction effects attract uniformly positive coefficients, significantly so if rent seeking is gauged by the right to operate in regulated sectors or by access to longterm loans. This is consistent with rent-seeking related vertical integration augmenting firm market valuations only if managers subject themselves to credible external monitoring. Overall, this is plausible if such monitoring keeps insiders from appropriating most of the benefits of vertical integration and rent-seeking.

As a robustness check we substitute $V_{\max }$ for $V_{\text {mean }}$ and repeat the valuation regressions. The results are qualitatively similar to the tables. As another robustness check, we drop the diversification variable from the right-hand side to avoid multicollinearity. Our results are qualitatively identical.

Both vertical integration and valuation might be driven by latent institutional factors, rendering the statistical relation between them spurious. To address this, we repeat the valuation regressions including as additional controls the full set of institutional variables and their interaction terms with the rent-seeking and auditor variables. This does not qualitatively change our key results.

\section{Conclusion}


Patterns of vertical integration in China correspond well to likely regional transactions cost differences. Firms are more vertically integrated in regions with weak legal property rights protection, poor quality government and underdeveloped markets for inputs and products; these observations are consistent with vertical integration being used to overcome transaction difficulties where legal property rights protection and market disciplinary forces are weak and the government highly bureaucratic and disinclined to respect property rights. Firms whose managers have closer ties to bureaucrats are also more vertically integrated, consistent with vertical integration augmenting the returns to political rent seeking and foreclosing competition. These results persist after controlling for the effects of industry factors, local transportation infrastructure, input price uncertainty, years listed, and the degree of regional economic development.

Our evidence of the effects of vertical integration on firm market values is more mixed. Vertical integration associated with political rent seeking is negatively related to firm value in the absence of a "big four" auditor. However, in the presence of a "big four" auditor, this negative relationship switches signs. These results are consistent with any net benefits of vertical integration accruing to insiders absent a credible external monitor, but being shared with public shareholders in the presence of such a monitor.

These empirical results, taken as a whole, support a transactions costs explanation of vertical integration. They also point to vertical integration possibly being more than just a response to market imperfections stemming from weak legal institutions and market disciplinary forces. First, rent-seeking might also be involved - with vertical integration helping insiders profit from defective public institutions. More fundamentally, successive reforms are progressively separating business from government, but at markedly different paces in different parts of China. Where that separation is least advanced, State and Party officials are also freest to predate on private businesses. It may be that the only viable businesses in such regions are those owned by the potential predators, either de jure via direct state voting control or de jure via. Since 
these people are unlikely to be the most creative entrepreneurs, growth in these regions is triply impeded - by weak institutions forcing greater vertical integration, by rent-seeking diverting business earnings to political insiders, and by entrusting corporate governance to those political insiders (or their proxies) rather than to the most talented entrepreneurs.

This threefold self-reinforcing drag on economic growth should be of concern to Chinese policy makers because increasing interregional inequality is a potentially serious source of political instability. Fortunately, our findings regarding big four auditors suggest an escape if policy makers desire one: increased transparency can interrupt this cycle by limiting political insiders' wealth extraction.

The usual caveats apply. One country's experience need not extend to other economies. Nonetheless, the evidence here provides a benchmark for comparison with other emerging and transition economies with similar institutional asthenia. 


\section{References}

Acemoglu, D., Aghion, P., Griffith, R., Zilibotti, F., 2004. Vertical integration and technology: theory and evidence. Working paper 10997. National Bureau of Economic Research.

Acemoglu, D., Johnson, S., Mitton, T., 2005. Determinants of vertical integration: finance, contracts, and regulation. Working paper 11424. National Bureau of Economic Research.

Allen, F., Qian, J., Qian, M., 2005. Law, finance, and economic growth in China. Journal of Financial Economics 77 (1), 57-116.

Cabral, Luis, 2000. Introduction to Industrial Organization, MIT Press: Cambridge, Mass.

Carlton, D., 1979. Vertical integration in competitive markets under uncertainty. Journal of Industrial Economics 27 (3), 189-209.

Chaney, P., Jeter, D. Shivakumar L., 2004. Self selection of auditors and audit pricing in private firms, Accounting Review 79, 51-72

Che, J., Qian, Y., 1998. Insecure property rights and government ownership of firms. Quarterly Journal of Economics 113 (2), 467-496.

Chipty, T., 2001. Vertical integration, market foreclosure, and consumer welfare in the cable television industry, American Economic Review 91 (3), 428-453.

Coase, R., 1937. The nature of the firm. Economica 4, 386-405.

Cull, R., Xu, L., 2005. Institutions, ownership, and finance: the determinants of profit reinvestment among Chinese firms. Journal of Financial Economics 77 (1), 117-146.

Fan, G., Wang, X., 2001, 2002, 2003. NERI index of marketization of China's provinces. Economics Science Press, Beijing.

Fan, J., 2000. Price uncertainty and vertical integration: an examination of petrochemical firms. Journal of Corporate Finance 6, 345-376.

Fan, J., Goyal, V., 2006. On the patterns and wealth effects of vertical mergers. Journal of Business 79 (4), 877-902.

Fan, J., Lang, L., 2000. The measurement of relatedness: an application to corporate diversification. Journal of Business 73 (4), 629-660.

Fan, J., Wong, T., Zhang, T., 2007. Politically connected CEOs, corporate governance and postIPO performance of China's partially privatized firms. Journal of Financial Economics 84(2), 330-357.

Henisz, Witold, 2000. Institutional Environments for Multi-National Investment. Journal of Law, Economics and Organizations 16(2): 334-364.

Joskow, P., 1987. Contract duration and relationship-specific investments: empirical evidence from coal markets. American Economic Review 77 (1), 168-185. 
Khanna, Tarun, and K. G. Palepu, 1999. "Policy Shocks, Market Intermediaries, and Corporate Strategy: Evidence from Chile and India." Journal of Economics and Management Strategy $8(2), 271-310$

Khanna, Tarun and Felix Oberholzer-Gee, 2005, "The Political Economy of Firm-Size Distributions: Evidence from China," HBS working paper

Khawaja, A.L., and Mian, A., 2005. Do lenders favor politically connected firms? Rent provision in an emerging financial market, Quarterly Journal of Economics 120, 1371-1411.

Klein, B., Crawford, R., Alchian, A., 1978. Vertical integration, appropriable rents, and the competitive contracting process. Journal of Law and Economics 21, 297-326.

Klein, B., Leffler, K., 1981. The role of market forces in assuring contractual performance. Journal of Political Economy 89 (4), 615-641.

Lieberman, M., 1991. Determinants of vertical integration: an empirical test. Journal of Industrial Economics 39 (5), 451-466.

Li, P., Hou, Q., Jiang, M., Wang, C., 2004. The annual report of urban competitiveness in China. Social Sciences Academy, Beijing.

Lucas, Robert. E. Jr. 1978. "On the size distribution of business firms," Bell Journal of Economics, pp. 508-523.

Masten, S., 1984. The organization of production: evidence from the aerospace industry. Journal of Law and Economics 27, 403-418.

Milgrom, P., Roberts, J., 1988. An economic approach to influence activities in organizations. American Journal of Sociology, 94 (Supplement), 154-179.

Monteverde, K., Teece, D., 1982. Supplier switching costs and vertical integration in the automobile industry. Bell Journal of Economics 13 (1), 206-213.

Montinola, G., Qian, Y., Weingast, B., 1995. Federalism, Chinese style: the political basis for economic success in China. World Politics 48 (1), 50-81.

Mulherin, J., 1986. Complexity in long-term contracts: an analysis of natural gas contractual provisions. Journal of Law, Economics, and Organization 2 (1), 105-177.

Petersen, M., 2005. Estimating standard errors in financial panel data sets: comparing approaches. Working paper, Northwestern University.

Qian, Y., Weingast, B., 1996. China's transition to markets: market-preserving federalism, Chinese style. Journal of Policy Reform 1, 149-185.

Qian, Y., Weingast, B., 1997. Federalism as a commitment to preserving market incentives. Journal of Economic Perspectives 11 (4), 83-92.

Sapienza, P., 2004. The effects of government ownership on bank lending,” Journal of Financial Economics 72, 357-384. 
Stigler, G., 1951. The division of labor is limited by the extent of the market. Journal of Political Economy 59 (1), 185-193.

Titman, S., Trueman, B, 1986. Information quality and the valuation of new issues. Journal of Accounting and Economics 8, 159-172.

Williamson, O., 1973. Markets and hierarchies: some elementary considerations. American Economic Review 63 (2), 316-25.

Williamson, O., 1975. Markets and hierarchies: analysis and antitrust implications. Free, New York.

Williamson, O., 1979. Transaction cost economies: the governance of contractual relations. Journal of Law and Economics 22, 233-261. 
Table 1. The Sample

This table reports the sample by year and industry. Our sample consists of most nonfinancial, non-public utility listed companies in Shanghai and Shenzhen Stock Exchange from 2001 to 2003 . It totally has 2,765 firm-year observations.

\begin{tabular}{lcccc}
\hline \multicolumn{1}{c}{ Industry } & 2001 & 2002 & 2003 & Total \\
\hline Agriculture, Forestry and Fishing & 15 & 12 & 11 & 38 \\
Mining & 9 & 11 & 13 & 33 \\
Food and Beverages & 51 & 56 & 54 & 161 \\
Textile, Apparel and Leather & 39 & 42 & 37 & 118 \\
Lumber, Furniture, Paper and Printing & 23 & 28 & 29 & 80 \\
Petroleum, Chemicals, Rubber and Plastic & 111 & 109 & 118 & 338 \\
Products & 96 & 109 & 123 & 328 \\
Glass, Minerals and Metals & 210 & 233 & 242 & 685 \\
Machinery, Equipment and Instrument & 49 & 56 & 67 & 172 \\
Medicine and Biological Products & 15 & 19 & 20 & 54 \\
Construction & 130 & 136 & 150 & 416 \\
& 48 & 62 & 70 & 180 \\
Commerce & 50 & 53 & 51 & 154 \\
Real Estate $\quad 2$ & 3 & 3 & 8 \\
Services industries & 848 & 929 & 988 & 2765 \\
Publishing, Motion Pictures and Arts & 74.64 & 77.55 & 78.34 & 76.87 \\
\hline \multicolumn{1}{c}{ Percentage of total listed firms } & & & & \\
\hline
\end{tabular}


Table 2. The Patterns of Vertical Integration in China

This table presents the patterns of Chinese firms' vertical integration by year and industry. $V_{\text {mean }}$ and $V_{\max }$ are vertical integration measures based on the average method and the maximum method, respectively, as described in the text.

Panel A: $V_{\text {mean }}$ by Year

\begin{tabular}{ccccccc}
\hline Year & Obs. & Mean & Median & Std. Dev. & Min. & Max. \\
\hline 2001 & 848 & 0.0141 & 0.0086 & 0.0242 & 0.0000 & 0.2672 \\
2002 & 929 & 0.0138 & 0.0073 & 0.0254 & 0.0000 & 0.2672 \\
2003 & 988 & 0.0141 & 0.0078 & 0.0248 & 0.0000 & 0.2672 \\
Total & 2765 & 0.0140 & 0.0078 & 0.0248 & 0.0000 & 0.2672 \\
\hline
\end{tabular}

Panel B: $V_{\max }$ by Year

\begin{tabular}{ccccccc}
\hline Year & Obs. & Mean & Median & Std. Dev. & Min. & Max. \\
\hline 2001 & 848 & 0.0246 & 0.0131 & 0.0461 & 0.0000 & 0.5299 \\
2002 & 929 & 0.0242 & 0.0123 & 0.0486 & 0.0000 & 0.5299 \\
2003 & 988 & 0.0249 & 0.0127 & 0.0474 & 0.0000 & 0.5299 \\
Total & 2765 & 0.0246 & 0.0127 & 0.0474 & 0.0000 & 0.5299 \\
\hline
\end{tabular}

Panel C: Vertical Integration by Industry

\begin{tabular}{lccccc}
\multicolumn{1}{c}{ Industry } & \multirow{2}{*}{ Obs } & \multicolumn{2}{c}{$V_{\text {mean }}$} & \multicolumn{2}{c}{$V_{\text {max }}$} \\
& & Mean & Median & Mean & Median \\
\hline Agriculture, Forestry and Fishing & 38 & 0.0285 & 0.0069 & 0.0561 & 0.0114 \\
Mining & 33 & 0.0432 & 0.0146 & 0.0699 & 0.0265 \\
Food and Beverages & 161 & 0.0145 & 0.0063 & 0.0281 & 0.0116 \\
Textile, Apparel and Leather & 118 & 0.0182 & 0.0058 & 0.0313 & 0.0078 \\
Lumber, Furniture, Paper and Printing & 80 & 0.0093 & 0.0050 & 0.0169 & 0.0082 \\
Petroleum, Chemicals, Rubber and & 338 & 0.0158 & 0.0110 & 0.0273 & 0.0190 \\
Plastic Products & 328 & 0.0181 & 0.0023 & 0.0343 & 0.0033 \\
Glass, Minerals and Metals & 685 & 0.0124 & 0.0038 & 0.0222 & 0.0058 \\
Machinery, Equipment and Instrument & 172 & 0.0069 & 0.0008 & 0.0130 & 0.0015 \\
Medicine and Biological Products & 54 & 0.0133 & 0.0116 & 0.0245 & 0.0214 \\
Construction & 416 & 0.0160 & 0.0166 & 0.0253 & 0.0270 \\
Commerce & 180 & 0.0051 & 0.0029 & 0.0077 & 0.0054 \\
Real Estate & 154 & 0.0109 & 0.0084 & 0.0176 & 0.0130 \\
Services & 8 & 0.0072 & 0.0077 & 0.0110 & 0.0114 \\
Publishing, Motion Pictures and Arts & & & & & \\
\hline
\end{tabular}


Table 3. Descriptive Statistics

This table provides the descriptive statistics of institutional variables and other control variables. 'Property rights' is the index of property rights protection. 'Government quality' is the index of government service quality. 'Market development' is the index of resource allocated by market. 'CEO affiliation' is a dummy variable equal to one if the CEO of a firm is or has been a bureaucrat of the central government, a local government or an industry bureau. 'Business privilege' is a dummy variable equal to one if one of the firm's industries is heavily regulated by government. 'Financial leverage' is a dummy variable equal to one if the firm's ratio of long-term debt to total assets is above the provincial median value. 'Auditor' is a dummy variable equal to one if the firm employs a 'Big Four' accounting firm as its external auditor. 'Price uncertainty' is the standard error of the residual of a detrending regression of a firm segment's industry-level annual primary input prices from 1980 to 2001. 'Transportation infrastructure' is measured as the length of transportation routes in a province divided by the total geographic area of the province. 'Size' is the natural logarithm of firm assets. 'Diversification' is the number of firm segments. 'Years listed' is the number of years since the firm went IPO. 'Per capita GDP' is the provincial per capita gross domestic product.

\begin{tabular}{ccccccc}
\hline Variable & Obs. & Mean & Median & Std. Dev. & Min. & Max. \\
\hline Property rights & $92^{\mathrm{a}}$ & 7.19 & 7.36 & 2.1885 & 0.00 & 13.15 \\
Government quality & 31 & 0.0939 & 0.0963 & 0.0159 & 0.0715 & 0.1235 \\
Market development & $92^{\mathrm{a}}$ & 3.85 & 5.52 & 6.6832 & -35.94 & 10.00 \\
CEO affiliation & 2765 & 0.2561 & 0.00 & 0.4365 & 0.00 & 1.00 \\
Business privilege & 2765 & 0.1208 & 0.00 & 0.3259 & 0.00 & 1.00 \\
Financial leverage & 2765 & 0.4973 & 0.00 & 0.5001 & 0.00 & 1.00 \\
Auditor & 2765 & 0.0709 & 0.00 & 0.2567 & 0.00 & 1.00 \\
Price uncertainty & 2765 & 22.1434 & 7.3923 & 25.5495 & 0.0305 & 67.5195 \\
Transportation & 93 & 0.4124 & 0.3753 & 0.2921 & 0.0184 & 1.4457 \\
infrastructure & & & & & & \\
Size & 2765 & 20.9124 & 20.8487 & 0.8347 & 17.5534 & 26.6102 \\
Diversification & 2765 & 2.5128 & 2.00 & 1.4497 & 1.00 & 12.00 \\
Years listed & 2765 & 5.2499 & 5.00 & 2.6743 & 1.00 & 17.00 \\
per capita GDP & 93 & 0.9430 & 0.6565 & 0.7167 & 0.2662 & 4.0646 \\
\hline a The 2001 data of Tibet are not available. & & & & & &
\end{tabular}


Table 4. Person Correlation of Coefficients

$V_{\text {mean }}$ and $V_{\max }$ are vertical integration measures calculated using the average method and the maximum method, respectively, as described in the text. 'Property rights' is the index of property rights protection. 'Government quality' is the index of government service. 'Market development' is the index of resource allocated by market. 'CEO affiliation' is a dummy variable equal to one if the CEO of a firm is or has been a bureaucrat of the central government, a local government or an industry bureau. 'Business privilege' is a dummy variable equal to one if one of the firm's industries is heavily regulated by government. 'Financial leverage' is a dummy variable equal to one if the firm's ratio of long-term debt to total assets is above the regional median value. 'Auditor' is a dummy variable equal to one if the firm employs a 'Big Four' accounting firm as its external auditor. 'Price uncertainty' is the standard error of the residual of a detrending regression of a firm segment's industry-level annual primary input prices from 1980 to 2001. 'Transportation infrastructure' is measured as the length of transportation routes in a province divided by the total geographic area of the province. 'Size' is the natural logarithm of firm assets. 'Diversification' is the number of firm segments. 'Listing years' is the number of years since the firm went IPO. 'per capita GDP' is the provincial per capita gross domestic product. P-values are in parentheses.

\begin{tabular}{|c|c|c|c|c|c|c|c|c|c|c|c|c|c|c|c|}
\hline & & $V_{\text {mean }}$ & $V_{\max }$ & 1 & 2 & 3 & 4 & 5 & 6 & 7 & 8 & 9 & 10 & 11 & 12 \\
\hline & $V_{\max }$ & $\begin{array}{l}0.9934 \\
(0.000)\end{array}$ & & & & & & & & & & & & & \\
\hline 1 & Property rights & $\begin{array}{r}-0.0581 \\
(0.002)\end{array}$ & $\begin{array}{c}-0.0599 \\
(0.002)\end{array}$ & & & & & & & & & & & & \\
\hline 2 & Government quality & $\begin{array}{c}-0.0802 \\
(0.000)\end{array}$ & $\begin{array}{c}-0.0839 \\
(0.000)\end{array}$ & $\begin{array}{l}0.1074 \\
(0.000)\end{array}$ & & & & & & & & & & & \\
\hline 3 & Market development & $\begin{array}{r}-0.0477 \\
(0.012)\end{array}$ & $\begin{array}{c}-0.0539 \\
(0.005)\end{array}$ & $\begin{array}{r}-0.0527 \\
(0.006)\end{array}$ & $\begin{array}{l}0.2961 \\
(0.000)\end{array}$ & & & & & & & & & & \\
\hline 4 & CEO affiliation & $\begin{array}{l}0.0955 \\
(0.000)\end{array}$ & $\begin{array}{l}0.0928 \\
(0.000)\end{array}$ & $\begin{array}{c}-0.0059 \\
(0.758)\end{array}$ & $\begin{array}{r}-0.0564 \\
(0.003)\end{array}$ & $\begin{array}{l}0.0634 \\
(0.001)\end{array}$ & & & & & & & & & \\
\hline 5 & Business privilege & $\begin{array}{l}0.1242 \\
(0.000)\end{array}$ & $\begin{array}{l}0.1286 \\
(0.000)\end{array}$ & $\begin{array}{c}-0.0539 \\
(0.005)\end{array}$ & $\begin{array}{c}-0.1004 \\
(0.000)\end{array}$ & $\begin{array}{c}-0.0008 \\
(0.968)\end{array}$ & $\begin{array}{l}0.0165 \\
(0.387)\end{array}$ & & & & & & & & \\
\hline 6 & Financial leverage & $\begin{array}{l}0.0469 \\
(0.014)\end{array}$ & $\begin{array}{l}0.0522 \\
(0.006)\end{array}$ & $\begin{array}{l}0.0102 \\
(0.591)\end{array}$ & $\begin{array}{l}0.0037 \\
(0.847)\end{array}$ & $\begin{array}{l}0.0084 \\
(0.660)\end{array}$ & $\begin{array}{r}-0.0051 \\
(0.789)\end{array}$ & $\begin{array}{l}0.0686 \\
(0.000)\end{array}$ & & & & & & & \\
\hline 7 & Auditor & $\begin{array}{c}-0.0313 \\
(0.099)\end{array}$ & $\begin{array}{c}-0.0302 \\
(0.113)\end{array}$ & $\begin{array}{l}0.1175 \\
(0.000)\end{array}$ & $\begin{array}{l}0.0750 \\
(0.000)\end{array}$ & $\begin{array}{l}0.0042 \\
(0.825)\end{array}$ & $\begin{array}{r}-0.0006 \\
(0.975)\end{array}$ & $\begin{array}{l}0.0446 \\
(0.019)\end{array}$ & $\begin{array}{l}0.0663 \\
(0.001)\end{array}$ & & & & & & \\
\hline 8 & Price uncertainty & $\begin{array}{l}0.0807 \\
(0.000)\end{array}$ & $\begin{array}{l}0.0581 \\
(0.002)\end{array}$ & $\begin{array}{l}0.0169 \\
(0.375)\end{array}$ & $\begin{array}{r}-0.0050 \\
(0.794)\end{array}$ & $\begin{array}{c}-0.0219 \\
(0.251)\end{array}$ & $\begin{array}{l}0.0312 \\
(0.101)\end{array}$ & $\begin{array}{l}0.2781 \\
(0.000)\end{array}$ & $\begin{array}{r}-0.0484 \\
(0.011)\end{array}$ & $\begin{array}{r}-0.0110 \\
(0.562)\end{array}$ & & & & & \\
\hline 9 & Transportation infrastructure & $\begin{array}{c}-0.0277 \\
(0.145)\end{array}$ & $\begin{array}{c}-0.0326 \\
(0.086)\end{array}$ & $\begin{array}{l}0.4954 \\
(0.000)\end{array}$ & $\begin{array}{l}0.4086 \\
(0.000)\end{array}$ & $\begin{array}{l}0.1088 \\
(0.000)\end{array}$ & $\begin{array}{r}-0.0397 \\
(0.037)\end{array}$ & $\begin{array}{c}-0.0989 \\
(0.000)\end{array}$ & $\begin{array}{l}0.0056 \\
(0.769)\end{array}$ & $\begin{array}{l}0.2246 \\
(0.000)\end{array}$ & $\begin{array}{l}0.0557 \\
(0.003)\end{array}$ & & & & \\
\hline 10 & Size & $\begin{array}{l}0.0546 \\
(0.004)\end{array}$ & $\begin{array}{l}0.0565 \\
(0.003)\end{array}$ & $\begin{array}{l}0.0601 \\
(0.002)\end{array}$ & $\begin{array}{l}0.1053 \\
(0.000)\end{array}$ & $\begin{array}{l}0.0637 \\
(0.001)\end{array}$ & $\begin{array}{l}0.0147 \\
(0.441)\end{array}$ & $\begin{array}{l}0.2280 \\
(0.000)\end{array}$ & $\begin{array}{l}0.2320 \\
(0.000)\end{array}$ & $\begin{array}{l}0.2853 \\
(0.000)\end{array}$ & $\begin{array}{l}0.0549 \\
(0.004)\end{array}$ & $\begin{array}{l}0.1733 \\
(0.000)\end{array}$ & & & \\
\hline 11 & Diversification & $\begin{array}{l}0.1797 \\
(0.000)\end{array}$ & $\begin{array}{l}0.1685 \\
(0.000)\end{array}$ & $\begin{array}{l}0.0357 \\
(0.061)\end{array}$ & $\begin{array}{l}0.0776 \\
(0.000)\end{array}$ & $\begin{array}{c}-0.0099 \\
(0.603)\end{array}$ & $\begin{array}{c}-0.0092 \\
(0.629)\end{array}$ & $\begin{array}{l}0.1200 \\
(0.000)\end{array}$ & $\begin{array}{l}0.0169 \\
(0.375)\end{array}$ & $\begin{array}{r}-0.0520 \\
(0.006)\end{array}$ & $\begin{array}{l}0.0288 \\
(0.130)\end{array}$ & $\begin{array}{l}0.0799 \\
(0.000)\end{array}$ & $\begin{array}{l}0.0422 \\
(0.027)\end{array}$ & & \\
\hline 12 & Years listed & $\begin{array}{r}-0.0571 \\
(0.003)\end{array}$ & $\begin{array}{c}-0.0623 \\
(0.001)\end{array}$ & $\begin{array}{l}0.2600 \\
(0.000)\end{array}$ & $\begin{array}{l}0.0375 \\
(0.049)\end{array}$ & $\begin{array}{c}-0.0130 \\
(0.494)\end{array}$ & $\begin{array}{l}0.0152 \\
(0.424)\end{array}$ & $\begin{array}{c}-0.1106 \\
(0.000)\end{array}$ & $\begin{array}{l}0.0177 \\
(0.353)\end{array}$ & $\begin{array}{l}0.0944 \\
(0.000)\end{array}$ & $\begin{array}{l}0.0338 \\
(0.076)\end{array}$ & $\begin{array}{l}0.2848 \\
(0.000)\end{array}$ & $\begin{array}{l}0.0145 \\
(0.447)\end{array}$ & $\begin{array}{l}0.0712 \\
(0.000)\end{array}$ & \\
\hline 13 & per capita GDP & $\begin{array}{r}-0.0195 \\
(0.305)\end{array}$ & $\begin{array}{r}-0.0235 \\
(0.218)\end{array}$ & $\begin{array}{l}0.4396 \\
(0.000)\end{array}$ & $\begin{array}{l}0.3974 \\
(0.000)\end{array}$ & $\begin{array}{r}-0.0324 \\
(0.089)\end{array}$ & $\begin{array}{r}-0.0681 \\
(0.000)\end{array}$ & $\begin{array}{r}-0.0953 \\
(0.000)\end{array}$ & $\begin{array}{l}0.0037 \\
(0.845)\end{array}$ & $\begin{array}{l}0.2184 \\
(0.000)\end{array}$ & $\begin{array}{l}0.0850 \\
(0.000)\end{array}$ & $\begin{array}{l}0.9065 \\
(0.000)\end{array}$ & $\begin{array}{l}0.1814 \\
(0.000)\end{array}$ & $\begin{array}{l}0.0969 \\
(0.000)\end{array}$ & $\begin{array}{l}0.2969 \\
(0.000)\end{array}$ \\
\hline
\end{tabular}




\section{Table 5. Vertical Integration Level Sorted by Firm Rent Seeking Potential}

This table reports the mean (Panel A) and median (Panel B) vertical integration levels of the sample firms sorted by their rent seeking potential. Vertical integration is alternately measured as $V_{\text {mean }}$ and $V_{\text {max }}$, as defined in the text. Rent seeking potential is alternately proxied by three variables: 'CEO affiliation' is a dummy variable equal to one if the CEO of a firm is or has been a bureaucrat of the central government, a local government or an industry bureau; 'Business privilege' is a dummy variable equal to one if one of the firm's industries is heavily regulated by government; 'Financial leverage' is a dummy variable equal to one if the firm's ratio of long-term debt to total assets is above the regional median value. ${ }^{* * *},{ }^{* *}$, and ${ }^{*}$ denote significance at the $1 \%, 5 \%$, and $10 \%$ level, respectively.

\begin{tabular}{|c|c|c|c|c|c|c|}
\hline \multirow[b]{2}{*}{$\begin{array}{l}\text { Subsample } \\
\text { criteria }\end{array}$} & \multicolumn{3}{|c|}{$V_{\text {mean }}$} & \multicolumn{3}{|c|}{$V_{\max }$} \\
\hline & $\begin{array}{l}\text { High rent } \\
\text { seeking } \\
\text { potential }\end{array}$ & $\begin{array}{l}\text { Low rent } \\
\text { seeking } \\
\text { potential }\end{array}$ & Difference & $\begin{array}{l}\text { High rent } \\
\text { seeking } \\
\text { potential }\end{array}$ & $\begin{array}{c}\text { Low rent } \\
\text { seeking } \\
\text { potential }\end{array}$ & Difference \\
\hline CEO affiliation & 0.0180 & 0.0126 & $0.0054^{\star \star *}$ & 0.0321 & 0.0220 & $0.0101^{* * *}$ \\
\hline $\begin{array}{l}\text { Business } \\
\text { privilege }\end{array}$ & 0.0223 & 0.0129 & $0.0094^{* * *}$ & 0.0410 & 0.0223 & $0.0187^{* \star *}$ \\
\hline $\begin{array}{l}\text { Financial } \\
\text { leverage }\end{array}$ & 0.0152 & 0.0128 & $0.0024^{* *}$ & 0.0271 & 0.0221 & $0.0050^{* * *}$ \\
\hline
\end{tabular}

\section{Panel B Median}

\begin{tabular}{ccccccc}
\hline $\begin{array}{c}\text { Subsample } \\
\text { criteria }\end{array}$ & $\begin{array}{c}\text { High rent } \\
\text { seeking } \\
\text { potential }\end{array}$ & $\begin{array}{c}V_{\text {mean }} \\
\text { Low rent } \\
\text { seeking } \\
\text { potential }\end{array}$ & Difference & $\begin{array}{c}\text { High rent } \\
\text { seeking } \\
\text { potential }\end{array}$ & $\begin{array}{c}V_{\max } \\
\text { Low rent } \\
\text { seeking } \\
\text { potential }\end{array}$ & Difference \\
\hline CEO affiliation & 0.0091 & 0.0072 & $0.0019^{* * *}$ & 0.0138 & 0.0120 & $0.0018^{* * *}$ \\
$\begin{array}{c}\text { Business } \\
\text { privilege }\end{array}$ & 0.0099 & 0.0077 & $0.0022^{* *}$ & 0.0170 & 0.0123 & $0.0047^{* * *}$ \\
$\begin{array}{c}\text { Financial } \\
\text { leverage }\end{array}$ & 0.0080 & 0.0077 & 0.0003 & 0.0131 & 0.0123 & 0.0008 \\
\hline
\end{tabular}




\section{Table 6. Heckman Corrected OLS Regressions of Vertical Integration}

This table reports Heckman corrected ordinary least squares regression results of vertical integration determination. In the first stage (Panel A), we estimate a probit model with the dependent variable equal to one if a firm is a multi-industry firm, or otherwise zero, while the independent variables include firm size (natural logarithm of total assets), market value of common equity to book value of common equity, the percentage of common shares held by government, the number of years since the firm went public, industry and year dummies. The results of the second stage regressions are reported in Panel $B$. The dependent variable is $V_{\text {mean }}$, a firm vertical integration measure as described in the text. On the right hand side, 'Property rights' is the index of property rights protection, 'Government quality' is the index of government service, 'Market development' is the index of resource allocated by market, 'CEO affiliation' is a dummy variable equal to one if the CEO of a firm is or has been a bureaucrat of the central government, a local government or an industry bureau, 'Business privilege' is a dummy variable that equals to one if one of the firm's industries is heavily regulated by government, 'Financial leverage' is a dummy variable equal to one if the firm's ratio of long-term debt to total assets is above the provincial median value, 'Price uncertainty' is the standard error of the residuals of a detrending regression of a firm segment's industry level annual primary input prices from 1980 to 2001, 'Transportation infrastructure' is the length of transportation routes in a province divided by the total geographic area of the province, 'Years listed' is the number of years since the firm went public, 'per capita GDP' is the provincial per capita gross domestic product. The inverse Mill's Ratio, $\lambda$, is estimated from the first stage regression. The regressions employ the OLS method with standard errors clustered at the firm and the year level (Petersen, 2005). $Z$ and $t$ statistics are in parentheses in Panel $A$ and $B$, respectively. ${ }^{* * *},{ }^{* *}$ and ${ }^{*}$ denote significance at $1 \%, 5 \%$ and $10 \%$ level, respectively. The sample size is smaller than the full sample, because of missing state ownership information of some firms.

Panel A The Selection Model of Multiple Segments

\begin{tabular}{ccc}
\hline & Coefficients & Z value \\
\hline Intercept & 1.0372 & $(1.47)$ \\
Firm Size & 0.0052 & $(0.17)$ \\
Market to Book Value & -0.0039 & $(-1.11)$ \\
State Ownership & $-0.7089^{* * *}$ & $(-3.35)$ \\
Years listed & $0.0433^{* * *}$ & $(4.15)$ \\
Industry dummies & & \\
Year dummies & & Included \\
Obs. & Included \\
Pseudo $\mathrm{R}^{2}$ & 2744 \\
\end{tabular}


Panel B The Second Stage Regressions

\begin{tabular}{|c|c|c|c|c|c|}
\hline & (1) & (2) & (3) & (4) & (5) \\
\hline Intercept & $\begin{array}{c}0.0181^{* * *} \\
(8.60)\end{array}$ & $\begin{array}{c}0.0385^{* * *} \\
(5.91)\end{array}$ & $\begin{array}{c}0.0367^{* * *} \\
(5.80)\end{array}$ & $\begin{array}{c}0.0373^{* * *} \\
(5.90)\end{array}$ & $\begin{array}{c}0.0377^{* * *} \\
(5.89)\end{array}$ \\
\hline Property rights & & $\begin{array}{c}-0.0008^{*} \\
(-1.92)\end{array}$ & $\begin{array}{c}-0.0008^{* *} \\
(-2.00)\end{array}$ & $\begin{array}{c}-0.0008^{*} \\
(-1.91)\end{array}$ & $\begin{array}{c}-0.0008^{*} \\
(-1.93)\end{array}$ \\
\hline Government quality & & $\begin{array}{c}-0.1563^{* * *} \\
(-2.90)\end{array}$ & $\begin{array}{c}-0.1458^{* * *} \\
(-2.79)\end{array}$ & $\begin{array}{c}-0.1486^{* * *} \\
(-2.85)\end{array}$ & $\begin{array}{c}-0.1576^{\star \star *} \\
(-2.92)\end{array}$ \\
\hline Market development & & $\begin{array}{c}-0.0002^{*} \\
(-1.84)\end{array}$ & $\begin{array}{c}-0.0002^{* *} \\
(-2.12)\end{array}$ & $\begin{array}{c}-0.0002^{* *} \\
(-1.97)\end{array}$ & $\begin{array}{c}-0.0002^{*} \\
(-1.85)\end{array}$ \\
\hline CEO affiliation & & & $\begin{array}{c}0.0048^{* * *} \\
(3.60)\end{array}$ & & \\
\hline Business privilege & & & & $\begin{array}{c}0.0083^{* * *} \\
(4.09)\end{array}$ & \\
\hline Financial leverage & & & & & $\begin{array}{c}0.0029^{* * *} \\
(3.36)\end{array}$ \\
\hline$\lambda$ & $\begin{array}{c}-0.0180^{* * *} \\
(-6.32)\end{array}$ & $\begin{array}{c}-0.0182^{* * *} \\
(-6.38)\end{array}$ & $\begin{array}{c}-0.0184^{* * *} \\
(-6.44)\end{array}$ & $\begin{array}{c}-0.0178^{\star * *} \\
(-6.14)\end{array}$ & $\begin{array}{c}-0.0186^{* * *} \\
(-6.54)\end{array}$ \\
\hline Price uncertainty & $\begin{array}{c}0.0002^{* *} \\
(2.36)\end{array}$ & $\begin{array}{c}0.0002^{* *} \\
(2.36)\end{array}$ & $\begin{array}{c}0.0002^{* *} \\
(2.33)\end{array}$ & $\begin{array}{c}0.0001 \\
(1.16)\end{array}$ & $\begin{array}{c}0.0001^{* *} \\
(2.31)\end{array}$ \\
\hline Transportation infrastructure & $\begin{array}{c}-0.0001 \\
(-0.02)\end{array}$ & $\begin{array}{l}0.0055 \\
(1.22)\end{array}$ & $\begin{array}{l}0.0050 \\
(1.11)\end{array}$ & $\begin{array}{l}0.0055 \\
(1.22)\end{array}$ & $\begin{array}{c}0.0054 \\
(1.20)\end{array}$ \\
\hline \multicolumn{6}{|l|}{ Price uncertainty $x$} \\
\hline $\begin{array}{l}\text { Transportation } \\
\text { infrastructures }\end{array}$ & $\begin{array}{c}-0.0002^{* * *} \\
(-3.89)\end{array}$ & $\begin{array}{c}-0.0002^{* * *} \\
(-3.96)\end{array}$ & $\begin{array}{c}-0.0002^{* * *} \\
(-3.91)\end{array}$ & $\begin{array}{c}-0.0002^{* * *} \\
(-3.83)\end{array}$ & $\begin{array}{c}-0.0002^{* * *} \\
(-3.92)\end{array}$ \\
\hline Years listed & $\begin{array}{c}-0.0007^{* * *} \\
(-4.17)\end{array}$ & $\begin{array}{c}-0.0007^{* * *} \\
(-4.06)\end{array}$ & $\begin{array}{c}-0.0007^{* * *} \\
(-4.31)\end{array}$ & $\begin{array}{c}-0.0007^{* * *} \\
(-3.79)\end{array}$ & $\begin{array}{c}-0.0007^{* * *} \\
(-4.18)\end{array}$ \\
\hline per capita GDP & $\begin{array}{l}0.0016 \\
(1.15)\end{array}$ & $\begin{array}{l}0.0013 \\
(0.84)\end{array}$ & $\begin{array}{l}0.0015 \\
(1.02)\end{array}$ & $\begin{array}{l}0.0013 \\
(0.87)\end{array}$ & $\begin{array}{l}0.0013 \\
(0.83)\end{array}$ \\
\hline Year & Included & Included & Included & Included & Included \\
\hline Industry & Included & Included & Included & Included & Included \\
\hline $\begin{array}{l}\text { Obs. } \\
\text { Adj-R }\end{array}$ & $\begin{array}{c}2744 \\
0.0418\end{array}$ & $\begin{array}{c}2738 \\
0.0505\end{array}$ & $\begin{array}{c}2738 \\
0.0574\end{array}$ & $\begin{array}{c}2738 \\
0.0581\end{array}$ & $\begin{array}{c}2738 \\
0.0538\end{array}$ \\
\hline
\end{tabular}




\section{Table 7. Regression Results of Vertical Integration and Firm Value}

This table reports regression results of the performance effects of vertical integration. To mitigate potential selection effects of vertical integration and auditor selection, we employ the Heckman procedure. The inverse Mill's ratio, $\lambda$, associated with vertical integration, is from the probit model as in Panel A of Table 6 . The second inverse Mill's ratio, $\lambda_{2}$, associated with auditor choice, is from the probit regressions in Panel $A$ of this Table. The dependent variable equals to one if a firm's external auditor is 'Big Four'. The independent variables include: 'Size' as the natural logarithm of total assets; 'Asset Structure' as the current asset divided by current liability; 'Account Receivable' as the ratio of account receivable to total assets; 'Inventory' as the ratio of inventory to total assets. $Z$ statistics are in parentheses. (The Chi-Square is 240.13 , at $1 \%$ level significant.) The reduction of sample is because of the dropping of perfectly predicted observations in the probit regression. Panel $\mathrm{B}$ reports the second stage results. The dependent variable is a version of Tobin's q ratio, measured as the market value of equity plus book value of debt divided by total assets. Due to the coexistence of tradable and non-tradable shares in China, we use the fiscal year-end stock price to compute the market value of tradable shares, and use book value to proxy for the value of non-tradable shares. Vmean is the vertical integration measure defined in the text. 'Auditor' is a dummy variable equal to one if a firm employs a 'Big Four' accounting firm as its external auditor. Political connection is measured in three alternative ways: 'CEO affiliation' is a dummy variable equal to one if the CEO of a firm is or has been a bureaucrat of the central government, a local government or an industry bureau; 'Business privilege' is a dummy variable equal to one if one of the firm's industries is heavily regulated; 'Financial leverage' is a dummy variable equal to one if the firm's ratio of long-term debt to total assets is above the provincial median value. 'Diversification' is the number of the firm segments. 'Size' is the natural logarithm of firm assets. 'Debt ratio' is defined as total debt divided by total assets. 'Growth' is measured as annual percentage growth in sales. 'State ownership' is the percentage of common shares owned by government. 'Years listed' is the number of years since the firm went public. Considering the high correlation between financial leverage and debt ratio, we don't include debt ratio in the regression when using financial leverage as firms' political connection measure. The regressions employ the OLS method with standard errors clustered at the firm and the year level (Petersen, 2005). T-statistics are in parentheses. ${ }^{* * *},{ }^{* *}$ and ${ }^{*}$ denote significance at $1 \%, 5 \%$ and $10 \%$ level, respectively.

Panel A The Selection Model of Auditor

\begin{tabular}{ccc}
\hline & Coefficients & Z value \\
\hline Intercept & $-15.7708^{* \star *}$ & $(-12.97)$ \\
Size & $0.6536^{* \star *}$ & $(12.64)$ \\
Asset Structure & $0.0494^{* *}$ & $(2.63)$ \\
Account Receivable & -0.8019 & $(-1.39)$ \\
Inventory & -0.0406 & $(-0.11)$ \\
Industry dummies & & \\
Year dummies & & Included \\
Obs. & Included \\
Pseudo $R^{2}$ & \multicolumn{2}{c}{2638} \\
\end{tabular}


Panel B The Performance of Vertical Integration

\begin{tabular}{|c|c|c|c|c|}
\hline & (1) & $\begin{array}{c}\text { (2) } \\
\text { CEO affiliation }\end{array}$ & $\begin{array}{c}\text { (3) } \\
\text { Business } \\
\text { privilege }\end{array}$ & $\begin{array}{c}(4) \\
\text { Financial } \\
\text { leverage }\end{array}$ \\
\hline Intercept & $\begin{array}{l}7.8461^{\text {*** }} \\
(27.91)\end{array}$ & $\begin{array}{c}10.6135^{\text {*त* }} \\
(9.80)\end{array}$ & $\begin{array}{c}11.5104^{\text {*** }} \\
(11.12)\end{array}$ & $\begin{array}{l}9.4598^{\text {*** }} \\
(10.09)\end{array}$ \\
\hline$V_{\text {mean }}$ & $\begin{array}{c}-0.1296 \\
(-0.49)\end{array}$ & $\begin{array}{l}0.5863 \\
(1.40)\end{array}$ & $\begin{array}{l}0.5802 \\
(1.11)\end{array}$ & $\begin{array}{c}1.3902^{*} \\
(1.83)\end{array}$ \\
\hline Political connection & & $\begin{array}{c}0.0202 \\
(0.89)\end{array}$ & $\begin{array}{c}0.0534^{* *} \\
(1.97)\end{array}$ & $\begin{array}{c}-0.0268 \\
(-1.30)\end{array}$ \\
\hline Auditor & & $\begin{array}{c}0.1747^{* * *} \\
(4.15)\end{array}$ & $\begin{array}{c}0.1685^{* * *} \\
(4.17)\end{array}$ & $\begin{array}{c}0.1675^{* * *} \\
(4.25)\end{array}$ \\
\hline$V_{\text {mean }} \times$ Political connection & & $\begin{array}{c}-1.3863^{* *} \\
(-2.56)\end{array}$ & $\begin{array}{r}-1.2309^{* *} \\
(-2.12)\end{array}$ & $\begin{array}{c}-1.8547^{* *} \\
(-2.37)\end{array}$ \\
\hline$V_{\text {mean }} \times$ Auditor & & $\begin{array}{l}0.2447 \\
(0.09)\end{array}$ & $\begin{array}{c}-0.2703 \\
(0.16)\end{array}$ & $\begin{array}{l}-2.8687 \\
(-1.57)\end{array}$ \\
\hline $\begin{array}{c}V_{\text {mean }} \times \text { Political } \\
\text { connection } \times \text { Auditor }\end{array}$ & & $\begin{array}{l}3.1875 \\
(1.02)\end{array}$ & $\begin{array}{c}13.5874^{\star *} \\
(2.38)\end{array}$ & $\begin{array}{c}6.7747^{* *} \\
(2.48)\end{array}$ \\
\hline Diversification & $\begin{array}{c}-0.0116^{* *} \\
(-2.12)\end{array}$ & $\begin{array}{c}-0.0112^{* *} \\
(-1.97)\end{array}$ & $\begin{array}{c}-0.0137^{* *} \\
(-2.31)\end{array}$ & $\begin{array}{c}-0.0114^{* *} \\
(-2.04)\end{array}$ \\
\hline$\lambda$ & $\begin{array}{l}0.0538 \\
(0.69)\end{array}$ & $\begin{array}{l}0.1239 \\
(1.57)\end{array}$ & $\begin{array}{l}0.1245 \\
(1.60)\end{array}$ & $\begin{array}{l}0.1312 \\
(1.61)\end{array}$ \\
\hline$\lambda_{2}$ & & $\begin{array}{r}-0.1892^{* *} \\
(-2.37)\end{array}$ & $\begin{array}{c}-0.2452^{* \star *} \\
(-3.21)\end{array}$ & $\begin{array}{c}-0.0909 \\
(1.29)\end{array}$ \\
\hline Size & $\begin{array}{l}-0.3168^{* * *} \\
(-23.91)\end{array}$ & $\begin{array}{c}-0.4351^{* * *} \\
(-9.22)\end{array}$ & $\begin{array}{l}-0.4736^{\star * *} \\
(-10.49)\end{array}$ & $\begin{array}{c}-0.3845^{* * *} \\
(-9.50)\end{array}$ \\
\hline Debt ratio & $\begin{array}{c}0.1471^{* *} \\
(1.99)\end{array}$ & $\begin{array}{l}0.1760^{* *} \\
(2.05)\end{array}$ & $\begin{array}{c}0.1788^{* *} \\
(2.09)\end{array}$ & \\
\hline Growth & $\begin{array}{l}0.0133 \\
(0.90)\end{array}$ & $\begin{array}{l}0.0108 \\
(0.71)\end{array}$ & $\begin{array}{l}0.0115 \\
(0.76)\end{array}$ & $\begin{array}{l}0.0100 \\
(0.65)\end{array}$ \\
\hline State ownership & $\begin{array}{c}-0.2100^{* * *} \\
(-3.11)\end{array}$ & $\begin{array}{c}-0.1862^{* * *} \\
(-2.71)\end{array}$ & $\begin{array}{c}-0.1873^{* * *} \\
(-2.73)\end{array}$ & $\begin{array}{c}-0.2095^{* * *} \\
(-3.05)\end{array}$ \\
\hline Years listed & $\begin{array}{c}0.0405^{\star \star \star} \\
(9.96)\end{array}$ & $\begin{array}{c}0.0386^{\star * *} \\
(9.30)\end{array}$ & $\begin{array}{c}0.0388^{* * *} \\
(9.40)\end{array}$ & $\begin{array}{l}0.0439^{* * *} \\
(10.39)\end{array}$ \\
\hline $\begin{array}{c}\text { Year } \\
\text { Industry }\end{array}$ & $\begin{array}{l}\text { Included } \\
\text { Included }\end{array}$ & $\begin{array}{l}\text { Included } \\
\text { Included }\end{array}$ & $\begin{array}{l}\text { Included } \\
\text { Included }\end{array}$ & $\begin{array}{l}\text { Included } \\
\text { Included }\end{array}$ \\
\hline Obs. & 2739 & 2622 & 2622 & 2622 \\
\hline Adj- $R^{2}$ & 0.3713 & 0.3798 & 0.3819 & 0.3752 \\
\hline
\end{tabular}


Appendix: Variable Definitions

Variable

Definition

Data source

Legal Property The index of property rights protection, which measures

rights the suit frequency and court efficiency. The frequency of lawsuits is defined as the number of business or economic lawsuits scaled by a location's GDP in constant "yuan". The court efficiency is the number of economic or business lawsuits concluded by the court in a year divided by number of cases filed in the year.

Government
quality

Market development

Auditor

CEO affiliation

Business

privilege

Financial

leverage

Price uncertainty

The index of government service, which measures the level of bureaucratization, the frequency of government expropriation and the level of citizen satisfaction.

An index, constructed to be inversely related to a local government's fiscal expenditure scaled by GDP, which captures the extent to which a province's resources are allocated by markets.

Whether a firm's external auditor is a 'Big Four' firm.

Whether a firm's CEO is or has been a bureaucrat of the central government, a local government or an industry bureau.

Whether one of the firm's industries is heavily regulated by government, such as coal, steel, petroleum, natural gas, water supply, mental, aircraft, electricity, railroads, aviation, finance, post and telecom.

whether financial leverage of the firm is above the median of all firms in the same province.

The standard error of the residual of a detrending regression of a firm segment's industry annual primary input prices from 1980 to 2001

Transportation The length of transportation routes (highway, railway, and infrastructure waterway) in a province divided by the total geographic area of the province

Diversification The number of firm segments

Tobin's q

Market value of firm divided by firm assets. The market value is measured as the market value of common equity plus the book value of debt. Due to the coexistence of tradable and non-tradable shares in China, we use the fiscal year-end stock price to calculate the market value of tradable shares, and use book value to proxy for the value of non-tradable shares

Size The natural logarithm of firm assets

Debt ratio The ratio of total debt to total assets

Growth The annual percentage growth in firm sales

State ownership The percentage of common shares owned by government

Years listed The years since IPO

per capita GDP The provincial per capita GDP, unit: ten thousand
Fan and Wang

(various years)

Annual Report on

Urban

Competitiveness in China

Fan and Wang

(various years)

CSMAR $^{a}$

Fan, Wong and Zhang

(forthcoming)

Corporate Annual Report

CSMAR

China Price

Yearbook

China Statistical

Almanac

Corporate Annual Report

CSMAR

CSMAR

CSMAR

CSMAR

Corporate Annual

Report

CSMAR

China Statistical

Almanac

CSMAR is China Stock Market \& Accounting Research Database, developed by Hong Kong Polytechnic University and Shenzhen GTA Information Technology Co. Ltd. 